once the diagnosis of haemorrhage has been made.

1 Thompson DNP, Taylor W, Hayward RD. Silastic dural substitute. Experience of its use in spinal and foramen magnum surgery. Br $\mathcal{F}$ Neurosurg 1994 (in press).

2 Adegbite AB, Paine KWE, Rozdilsky B. The role of neomembranes in formation of hematoma around silastic dural substitute. Case report. $\mathcal{F}$ Neurosurg 1983;58: tic dural

3 Misra BK, Shaw JF: Extracerebral haematoma in association with dural substitute. Neurosurgery 1987;21. tion with

4 Fontana R, Talmonti G, D'Angelo V, Arena O, Monte V, Collice M: Spontaneous haematoma as unusual complication of Silastic dural substitute. Report of 2 cases.
Acta Neurochir (Wien) 1992;115:64-6.

5 Banergee T, Meagher JN, Hunt WE: Unusual complications with use of Silastic dural substitute. Am Surg 1974;40:434-7.

6 Ongkiko CM, Keller JT, Mayfield FH, Dunsker SB: An unusual complication of Dura film as a dural substitute. f Neurosurg 1984;60:1076-9.

7 Awwad EE, Smith KR, Martin DS, Manepalli A: Unusual haemorrhage with use of synthetic dural substitute: MR findings. F Computer Assist Tomog 1991;15:618-20.

8 Simpson D, Robson A. Recurrent subarachnoid bleeding in association with dural substitute. $\mathcal{F}$ Neurosurg 1984; 60:408-9.

9 Boop FA, Chadduck WM: Silastic duraplasty in pediatric patients. Neurosurgery 1991;29:785-8.

10 Anonymous: Tethered spinal cord Lancet 1986;ii: 549-50.

11 Hall WA, Albright AL, Brunberg JA: Diagnosis of tethered cords by magnetic resonance imaging. Surg Neurol 1988;30:60-4.

\section{John and James Parkinson on appendicitis}

Though straying from the strict confines of neurology, one of the classic, early accounts of appendicitis may be of interest. The extraordinarily versatile James Parkinson $^{1}$ read this paper on 21 January $1812 .^{2}$

... a boy about 5 years of age, who died under the following circumstances.

He had been observed for some time to decline in health, but made no particular complaint until two days before his death when he was suddenly seized with vomiting and great prostration of strength. The abdomen became very tumid and painful upon being pressed; his countenance pale and sunken, his pulse hardly perceptible. Death preceded by extreme restlessness and delirium, took place with 24 hours.

Upon examination the whole surface of the peritoneum was found inflamed with a thin coat of coagulable lymph; ... The viscera independent of the inflammation of the peritoneal covering, appeared in a perfectly healthy state, excepting the appendix vermiformis of the coecum. No diseased appearance was seen in this part near to the coecum; but about an inch of its extremity was considerably enlarged and thickened, its internal surface ulcerated, and an opening from ulceration which would have admitted a crow quill, was found at the commencement of the diseased part, about the middle of the appendix, through which it appeared, that a thin dark-coloured and highly fetid fluid, had escaped into the cavity of the abdomen. Upon opening the appendix, a piece of hardened foeces was found impacted...

It is often overlooked that the title of this paper is subheaded: "By John Parkinson, Esq., Surgeon. Communicated by James Parkinson, Esq.".

James had married Mary Dale in May 1781 and they had six children: two died in infancy, one son John qualified in Medicine and shared his practice. I remain unsure as to who made this major contribution.

$$
\begin{array}{r}
\text { JMS PEARCE } \\
304 \text { Beverley Road, } \\
\text { Anlaby, Hull HU10 } 7 B G, U K
\end{array}
$$

1 Pearce JMS. Aspects of the history of Parkinson's Disease. f Neurol Neurosurg Psychiatry 1989;52 suppl:6-10.

2 Parkinson J. Case of diseased appendix vermiformis. Med Chir Trans, 1812;III:57. Cited in: Classic descriptions of disease, 3rd edn, Ralph H Major, ed. Oxford: Blackwell, $1945 ; 652$. 